\title{
Polychlorinated biphenyls and organochlorine pesticide levels in tissues of Caretta caretta from the Adriatic Sea
}

\author{
M. Perugini ${ }^{1, *}$, A. Giammarino ${ }^{1}$, V. Olivieri ${ }^{2}$, S. Guccione ${ }^{3}$, O. R. Lai ${ }^{4}$, M. Amorena ${ }^{1}$ \\ ${ }^{1}$ Department of Food Sciences, Teramo University, Viale Crispi 212, 64100 Teramo, Italy \\ ${ }^{2}$ Executive Veterinary A.S.L. Pescara, Via Pantini 60, 65100 Pescara, Italy \\ ${ }^{3}$ Biologist, Via Pantini 60, 65100 Pescara, Italy \\ ${ }^{4}$ Department of Animal Health and Welfare, Bari University, 70010 Bari, Italy
}

\begin{abstract}
We detected concentrations of polychlorinated biphenyls (PCBs) and organochlorine pesticides (OCs) in the liver, muscle, and fat of 11 loggerhead sea turtles Caretta caretta from the central and southern Adriatic Sea. All samples contained PCBs at various concentrations, with Congener $138(28 \%), 153(27 \%)$, and $180(32 \%)$ dominating the congener composition of the tissues. The dioxin-like congener $(118,13 \%)$ was detected in all tissues analyzed. The lower-chlorinated PCBs were not detected. The average of the total PCB concentrations, expressed in nanograms per gram wet weight, was $459.6 \mathrm{ng} \mathrm{g}^{-1}$ in fat, $82.9 \mathrm{ng} \mathrm{g}^{-1}$ in liver, and $5.8 \mathrm{ng} \mathrm{g}^{-1}$ in muscle. Among 13 organochlorine pesticides for which analyses were conducted, 4 were detected: $p, p^{\prime}-\mathrm{DDE}(57 \%)$; $p, p^{\prime}$-DDD (16\%); and $p, p^{\prime}$-DDT and $o, p^{\prime}$-DDT (27\%). Spatial differences were found among OC concentrations in loggerheads from the central and southern Adriatic Sea. The only samples containing detectable concentrations of $p, p^{\prime}$-DDT and $o, p^{\prime}$-DDT were from the southern area.
\end{abstract}

KEY WORDS: Caretta caretta $\cdot$ Polychlorinated biphenyls · Organochlorine pesticides · Adriatic Sea · Marine pollution

Resale or republication not permitted without written consent of the publisher

\section{INTRODUCTION}

Caretta caretta is the most common sea turtle in the Mediterranean Sea. Even though it prefers the Greek, Turkish, and North African coasts for nesting, it uses the Adriatic Sea as a feeding ground. Usually, after leaving nesting beaches, hatchling, posthatchling, and small immature stages in the Mediterranean Sea live in a strictly oceanic pelagic phase, feeding primarily on pelagic prey. Progressively reaching maturity, they enter a benthic phase, feeding on benthic invertebrates in shallow coastal waters, on rocky coasts, and in coastal lagoons, bays, and creeks (Laurent et al. 1998, Bjorndal et al. 2000, Casale et al. 2003).

The loggerhead eats primarily fish, crustaceans, mollusks, algae, coelenterates, sea urchins, and even jellyfish, an omnivorous feeding behavior that is mainly carnivorous (Basso 1992). During periods of food abundance these species grow to a large size, increasing their body weight; they also accumulate fat stores for use when food is scarce. Sea turtles are longlived animals, with late sexual maturity (estimated to be 21 to $35 \mathrm{yr}$ for the loggerhead) and a long period of puberty (Laurent et al. 1990, Limpus 1990, Snover 2002).

Sea turtles are located at the top of the marine food chain and, despite being migratory, which inhibits their use as geographical indicators, represent a good indicator of sea health and marine pollution (Basso 1992). Moreover, their long migrations enhance their exposure to different chemical pollutants and their long life allows time for them to accumulate persistent organic compounds (Keller et al. 2004).

Italian legislation protects Caretta caretta (D.M. 1989). Globally the species is considered to be threatened with extinction by the US Endangered Species 
Act, and it has been included on the list of protected species by the Barcelona Convention (Convention on the Protection of the Mediterranean Sea from Pollution).

Marine pollution caused by persistent organic pollutants (POPs), and resultant diseases, human activities such as the development of tourism, coastal urbanization, and naval traffic, and particularly incidental fisheries capture are potential threats to the survival of Caretta caretta in the Mediterranean Sea (Laurent et al. 1996, Bentivegna et al. 2002).

Organic pollutants such as polychlorinated biphenyls (PCBs) and organochlorine pesticides (OCs) are a class of anthropogenic contaminants of longstanding environmental concern (Livingstone et al. 2000). They are characterized by great chemical stability and high persistence, with body burden and environmental half-life measured in decades. PCBs were manufactured from the 1930s to the 1970s for a range of industrial applications, such as liquid coolants for transformers used in the electricity supply or as softeners in the production of plastics and as components of hydraulic fluids and lubricating oils. DDTs, first synthesized in 1874, were used during World War II for public health protection, due to the ravages of malaria, and later on for pest control or to increase crop yield (Fernandez et al. 2004). The massive and uncontrolled use of these chemical compounds in addition to their high thermo-stability and their resistance to complete biodegradation caused their widespread diffusion to all environmental habitats, including marine ecosystems. The toxicological effects of PCBs and OCs should not be underestimated; these compounds are able to bioaccumulate through the food chain and their effects have been shown on the immune, endocrine, developmental, and reproductive systems of several different species (Fox 2001). Though the Adriatic Sea is a relatively shallow, land-locked water body, it differs from the other seas in physico-chemical and biological characteristics and represents a very productive ecosystem. However, it also remains the final recipient for terrestrial wastewater containing chemical pollutants, the cause of terrestrial and aquatic damage. PCBs and OCs were banned from use in Europe during the 1970s; however, they continue to be detected in the marine environment, and their presence in the Adriatic Sea has been extensively documented (Corsolini et al. 2000, Storelli \& Marcotrigiano 2000, Corsi et al. 2001, Focardi et al. 2001, Perugini et al. 2004). Published information concerning their presence, baseline levels, and effects on post-yearling turtles are less numerous, although the monitoring of toxic compounds is an important aspect for managing endangered and threatened species such as sea turtles, which could be particularly susceptible to the environmental changes caused by human activity.

The aim of this study was to evaluate the presence, congener distribution, and trends of 7 PCBs $(28,52,101$, $118,138,153$, and 180) and 13 OCs $\left(p, p^{\prime}\right.$-DDE, $p, p^{\prime}-$ DDD, $p, p^{\prime}$-DDT, $o, p^{\prime}$-DDT, alpha-endosulfan, betaendosulfan, alpha-hexachlorocyclohexane ( $\mathrm{HCH})$, beta-HCH, gamma-HCH, heptachlor, heptachlor epoxide, hexachlorobenzene, and methoxychlor) in loggerhead sea turtles stranded along the central and southern Adriatic coast in late 2003 and and late 2004, as well as to find any variation in accumulation levels among liver, pectoral muscle, and adipose tissue.

\section{MATERIALS AND METHODS}

Sample collection. We collected and analyzed 11 sea turtles Caretta caretta, some of which were found dead as a result of incidental fisheries capture or stranded in the years 2003 to 2004 (Table 1). The first 4 turtles, coming from the southern Adriatic Sea, were provided by the University of Bari; the rest of the turtles, from the central Adriatic Sea, were provided by the Centro Studi Cetacei (Fig. 1). Turtle 4 was rescued alive and was treated, but subsequently died in the Marine Biology Center of Bari. Analyses were carried out on liver, adipose, and muscle tissues of individual turtles. For the majority of the subjects, the approximate time of death was recorded within 24 h. For Turtles 6 and 7, it was not possible to collect the adipose tissue, because they were very thin. The curved carapace length and weight of each turtle was measured (Table 1). Biometrics data and sampling sites are shown in Table 1. Tissue samples were wrapped in aluminium foil and placed on ice for transport to the laboratory, where they were stored at $-80^{\circ} \mathrm{C}$ until analysis.

Sample preparation. Tissue samples were homogenized using a commercial blender and extracted (2 g) using an accelerated solvent extractor (ASE 100 Dionex). The fat content of each tissue was determined. Fat extraction was performed with a pressurized 1:1 (v/v) mixture of $\mathrm{n}$-hexane-acetone, using a Dionex ASE 100 instrument. Organic solvents were allowed to evaporate until dryness, then the fat content was determined by gravimetry. A second subsample (5 g) was extracted for analysis of contaminants. Pesticide-grade reagents and solvents were used, and the extractions were carried out using a 50:50 methylene chloride:hexane solution (Huwe 2002). The extracts were evaporated to dryness under a flow of nitrogen (max. temperature was $50^{\circ} \mathrm{C}$ ) and then taken up in hexane. The cleanup was carried out by concentrated sulfuric acid in the fat fraction previously dissolved in hexane, following the procedure described 
Table 1. Caretta caretta. Biometry and sampling information (l: liver tissue; f: fat tissue; m: muscle tissue)

\begin{tabular}{|lcccccc|}
\hline $\begin{array}{l}\text { Turtle } \\
\text { number }\end{array}$ & Site & $\begin{array}{c}\text { Carapace } \\
(\mathrm{cm})\end{array}$ & $\begin{array}{c}\text { Weight } \\
(\mathrm{kg})\end{array}$ & Tissue & $\begin{array}{c}\text { Approximate time } \\
\text { since death }(\mathrm{h})\end{array}$ & $\begin{array}{c}\text { Probable cause } \\
\text { of death }\end{array}$ \\
\hline 1 & Southern Adriatic & $51 \times 40$ & 8 & $1, \mathrm{f}, \mathrm{m}$ & $>24$ & Incidental fisheries \\
2 & Southern Adriatic & $31 \times 28$ & 4 & $1, \mathrm{f}, \mathrm{m}$ & $>24$ & Unknown \\
3 & Southern Adriatic & $43 \times 38$ & 7 & $1, \mathrm{f}, \mathrm{m}$ & $>24$ & Incidental fisheries \\
4 & Southern Adriatic & $23 \times 19$ & 3 & $1, \mathrm{f}, \mathrm{m}$ & $<24$ & Incidental fisheries \\
5 & Central Adriatic & $45.5 \times 40$ & 7 & $1, \mathrm{f}, \mathrm{m}$ & $<24$ & Unknown \\
6 & Central Adriatic & $30 \times 22$ & 3 & $1, \mathrm{~m}$ & $<24$ & Unknown \\
7 & Central Adriatic & $36 \times 25$ & 4 & $1, \mathrm{~m}$ & $<24$ & Unknown \\
8 & Central Adriatic & $38 \times 33$ & 6 & $1, \mathrm{f}, \mathrm{m}$ & $>24$ & Unknown \\
9 & Central Adriatic & $36 \times 33$ & 6 & $1, \mathrm{f}, \mathrm{m}$ & $<24$ & Unknown \\
10 & Central Adriatic & $70 \times 60$ & 8 & $1, \mathrm{f}, \mathrm{m}$ & $<24$ & Incidental fisheries \\
11 & Central Adriatic & $58 \times 56$ & 8 & $1, \mathrm{f}, \mathrm{m}$ & Unknown \\
\end{tabular}

by Pastor et al. (1993). After centrifugation, the organic phase was passed through a sodium sulfate anhydrous column, rinsed with hexane, concentrated under a flow of nitrogen, and stored at $4^{\circ} \mathrm{C}$ before analyzing by gas chromatography-mass spectrometry (GC-MS). An internal standard, ${ }^{13} \mathrm{C}_{12}$-labeled PCB 180 (provided by Dr. Ehrenstorfer) at a final concentration of $50 \mathrm{ng} \mathrm{g}^{-1}$, was added to the samples prior to cleanup, in order to quantify the compounds.

Analytical methods. Quantitative analysis of PCBs and OCs was carried out using a GC with electron impact (EI) (Shimadzu GC-MS QP 5000), mass selective detector and an autoinjector (Shimadzu AOC-20i) equipped with a capillary GC column $(30 \mathrm{~m} \times 0.25 \mathrm{~mm}$ i.d. $\times 0.25 \mu \mathrm{m}$ film thickness; Zebron ZB-5). The instrument used to determine $\mathrm{PCB}$ congeners ran using helium as carrier gas at a flow rate of $0.9 \mathrm{ml} \mathrm{min}^{-1}$. The oven was operated under the following conditions: $60^{\circ} \mathrm{C}, 2 \mathrm{~min}$ hold, ramp to $160^{\circ} \mathrm{C}$ at a rate of $20^{\circ} \mathrm{C} \mathrm{min}^{-1}$, $1 \mathrm{~min}$ hold, ramp to $240^{\circ} \mathrm{C}$ at a rate of $3^{\circ} \mathrm{C} \mathrm{min}{ }^{-1}, 3 \mathrm{~min}$ hold, ramp to $285^{\circ} \mathrm{C}$ at a rate of $5^{\circ} \mathrm{C} \mathrm{min}^{-1}$, with a final hold of $10 \mathrm{~min}$. Then, $2 \mu \mathrm{l}$ of sample was injected into a split/splitless injector used in splitless mode, with 2 min of injection time. For OC quantification, the

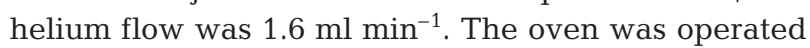
under the following conditions: $60^{\circ} \mathrm{C}, 2 \mathrm{~min}$ hold, ramp to $290^{\circ}$ at a rate of $10^{\circ} \mathrm{C} \mathrm{min}^{-1}, 15 \mathrm{~min}$ hold, with injection temperature $250^{\circ} \mathrm{C}$ and oven temperature programmed from 60 to $290^{\circ} \mathrm{C}$. Sample $(2 \mu \mathrm{l})$ was injected into a split/splitless injector used in splitless mode, with 2 min of injection time.

Two specific ions were chosen for each PCB and each OC. A single ion monitoring (SIM) program was constructed with a specific group start time (Table 2). Quantification was done using an internal standard. Pure reference standard solutions $\left(10 \mathrm{ng}^{-1} \mathrm{l}^{-1}\right.$ in isooctane) were used for instrument calibration, recovery determination, and quantification (Dr. Ehrenstorfer).
Prior to analysis of the samples, aliquots of commercial homogenized sole, used as blanks, were extracted and analyzed to check for cross-contamination. In addition, aliquots of the homogenized sole, spiked with standard mixtures at several concentration levels (ranging from 1 to $500 \mathrm{ng} \mathrm{g}^{-1}$ ), were extracted and analyzed in triplicate to evaluate the recovery. The recovery rate was between 80 and $110 \%$. Limits of quantification were: $1 \mathrm{ng}$ $\mathrm{g}^{-1}$ for the 7 PCB congeners; 1 ng g ${ }^{-1}$ for $p, p^{\prime}-\mathrm{DDE}, p, p^{\prime}-$ DDD, $p, p^{\prime}$-DDT, $o, p^{\prime}$-DDT, alpha-endosulfan, betaendosulfan, alpha-HCH, beta-HCH, and gamma-

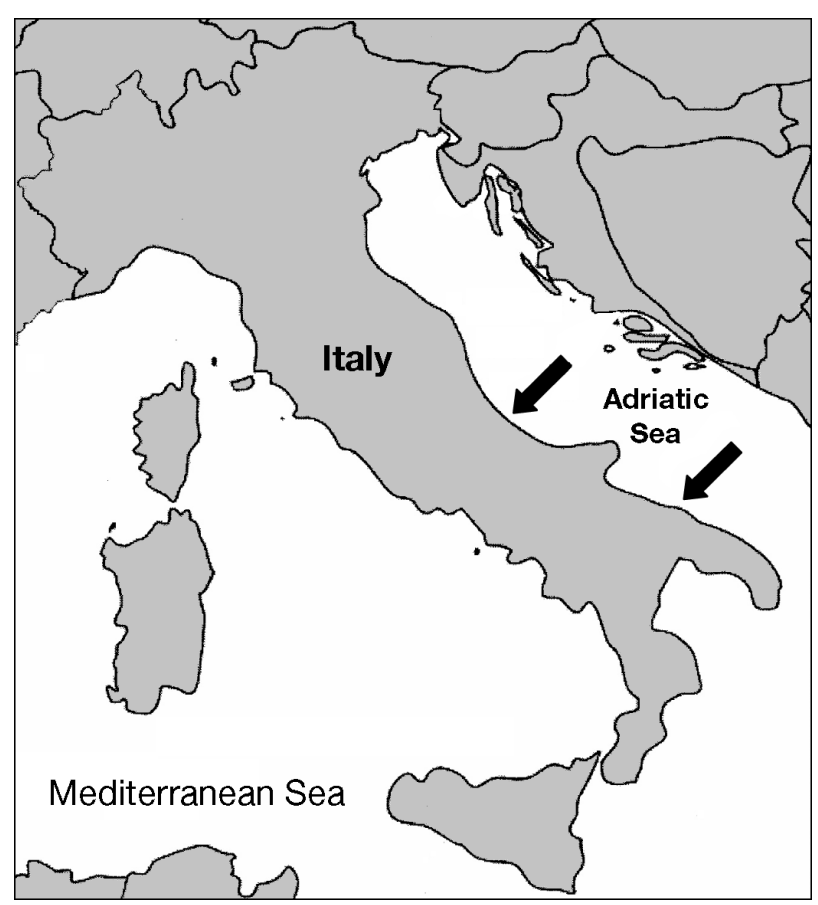

Fig. 1. Map of Italy showing the coast where sea turtles Caretta caretta were collected 
$\mathrm{HCH}$; and $5 \mathrm{ng} \mathrm{g}^{-1}$ for heptachlor, heptachlor epoxide, hexachlorobenzene, and methoxychlor.

Statistical analyses. Statistical data analysis was performed with SPSS 13.0.1 (SPSS). For all samples with concentrations below the limit of quantification, zero was used in the calculation. Normality of data for PCB and DDT compounds, calculated on a lipid basis and fresh basis, were assessed by the KolmogorovSmirnov test. They were not normally distributed, even after log transformation; therefore, only nonparametric statistical tests were used. In particular the KruskalWallis test was performed to detect significant differences among groups. Considering the dependent nature of some samples (organs), the Friedman test was performed. Moreover, correlation between variables was assessed using Spearman's correlation test.

Table 2. Reference ions and window break time of polychlorinated biphenyl (PCB) congeners and organochlorine (OC) pesticides

\begin{tabular}{lcc} 
Compound & Reference ions (M/Z) & Window break times \\
\hline PCB 28 & $256-258$ & $19-20.40$ \\
PCB 52 & $290-292$ & $20.50-22.30$ \\
PCB 101 & $326-328$ & $25-27.30$ \\
PCB 118 & $326-328$ & $29.50-30.50$ \\
PCB 138 & $360-362$ & $31-34$ \\
PCB 153 & $394-396$ & $31-34$ \\
PCB 180 & $406-408$ & $36.50-37.80$ \\
$p, p^{\prime}-$ DDE & $246-318$ & $20-21.10$ \\
$p, p^{\prime}-$ DDD & $235-237$ & $21.20-23.50$ \\
$o, p^{\prime}-$ DDT & $235-237$ & $21.20-23.50$ \\
$p, p^{\prime}-$ DDT & $235-237$ & $21.20-23.50$
\end{tabular}

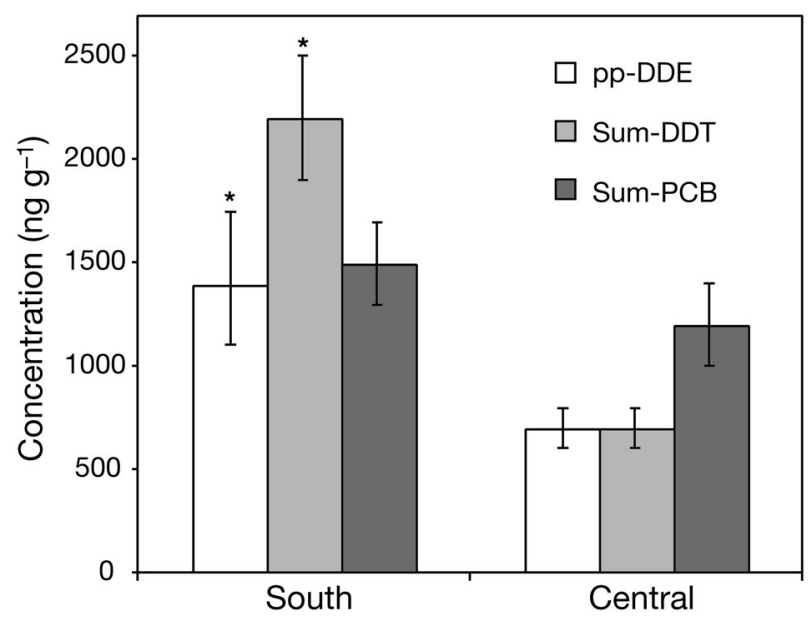

Fig. 2. Caretta caretta. Mean $\pm \mathrm{SD}$ of concentration of $\Sigma \mathrm{PCBs}$, $p, p^{\prime}$-DDE, and $\Sigma$ DDT in samples from the southern and central Adriatic Sea. Concentrations are expressed in nanograms per gram fat weight $\left({ }^{*} p<0.01\right)$

\section{RESULTS AND DISCUSSION}

\section{Organochlorine pesticides}

Of the 13 OC pesticides for which analyses were conducted, only 4 were detected in 1 or more samples. $p, p^{\prime}$-DDE was found in all turtles Caretta caretta analyzed and $p, p^{\prime}$-DDD, $p, p^{\prime}$-DDT, and $o, p^{\prime}$-DDT in those coming from the southern Adriatic Sea. The highly migratory nature of marine turtles limits their usefulness in evaluating the pollution of a specific area; however, this study found a significant spatial difference between OC contamination levels ( $p<0.01$ ). In particular, turtles from the southern Adriatic Sea showed higher levels of DDE and DDT than those coming from the central Adriatic Sea (Fig. 2). It is difficult to explain this pattern because production of DDT ceased in Italy by 1978. It could be presumed that exposure of sea turtles occurred in different areas to where they were collected, probably closer to developing countries where use of DDT has not yet been restricted. Studies on mitochondrial DNA (mtDNA) haplotypes have revealed that the Mediterranean population of loggerhead sea turtles constitutes an independent breeding stock, genetically independent from the Atlantic one. Further, Turkish colonies represent a distinct subpopulation, with unique genetic features (Laurent et al. 1998). In the future, it could be interesting to determine by PCR analysis the origin of our specimens, in order to correlate the pollutant concentrations found in them with their nesting areas. Furthermore, the concentrations of DDE and DDT compounds, found in liver, fat, and muscle, were not correlated to the carapace length of single subjects $\left(\mathrm{r}^{2}=0.1705\right.$ for liver, $\mathrm{r}^{2}=$ 0.0072 for fat, and $r^{2}=0.0075$ for muscle). The order of concentrations of pesticides was: $p, p^{\prime}$-DDE $>p, p^{\prime}$-DDT $>p, p^{\prime}$-DDD $>o, p^{\prime}$-DDT in all tissues. The average concentrations of $p, p^{\prime}$-DDE, expressed in nanograms per gram wet weight, were $40.5 \mathrm{ng} \mathrm{g}^{-1}$ in liver, $280.8 \mathrm{ng} \mathrm{g}^{-1}$ in fat, and $4.7 \mathrm{ng} \mathrm{g}^{-1}$ in muscle (Table 3 ). The contamination levels of organochlorine pesticides among tissues showed the following pattern: fat > liver > muscle, but significant differences were found among tissues only in concentrations on a wet weight $(p<0.01)$ but not on a fat weight basis ( $p>0.05)$. Concentrations detected in this study are quite similar to those reported in turtles beached along the southern Adriatic Sea (Storelli \& Marcotrigiano 2000), but higher than those found in turtles coming from the eastern Pacific Ocean (Gardner et al. 2003). However, according to other authors $p, p^{\prime}$-DDE is, in general, the pesticide present in the greatest concentrations in sea turtles, independent of the species selected and their geographical origin. In this study $p, p^{\prime}$-DDE represented $46 \%$ (in liver), $80 \%$ (in fat), and $64 \%$ (in muscle) of the total DDTs. 


\section{PCBs}

PCB results are listed in Table 3, and PCB congener composition is shown in Fig. 3. No significant spatial difference was found for PCBs in samples from the southern or central Adriatic Sea $(p>0.05)$. Of the 7 congeners for which the analyses were conducted, the dioxin-like congener (118) was detected in all tissues analyzed, but the concentrations of lower-chlorinated (tri-and tetra-) congeners were below the detection limit in all samples. In these samples the PCB pattern is not particularly variable among the tissues, showing no significant difference of each congener among liver, fat, and muscle tissues ( $p>0.05$ ). PCBs 138, 153, and 180, higher-chlorinated congeners, represent the greatest percent contribution to total PCBs. These results are in accordance with previous studies (Rybitski et al. 1995, McKenzie et al. 1999). On the one hand, this may be due to the possibility of highly chlorinated congeners (penta-, hexa-, and hepta-) increasing their concentrations while moving up the food chain and, on

Table 3. Caretta caretta. Average concentrations (ng g ${ }^{-1}$ wet wt) and minimum and maximum values of OC and PCB congeners in liver, adipose, and muscle tissues (LOD: limit of detection)

\begin{tabular}{|c|c|c|c|c|}
\hline & Conc. level & Liver & Fat & Muscle \\
\hline \% Lipid & Average & 5.9 & 38.7 & 0.5 \\
\hline$p, p^{\prime}-\mathrm{DDT}$ & $\begin{array}{l}\text { Average } \\
\text { Min. } \\
\text { Max. }\end{array}$ & $\begin{array}{r}19.6 \\
<\text { LOD } \\
70.6\end{array}$ & $\begin{array}{r}32.9 \\
<\text { LOD } \\
52.0\end{array}$ & $\begin{array}{r}1.3 \\
<\text { LOD } \\
2.6\end{array}$ \\
\hline$o, p^{\prime}-\mathrm{DDT}$ & $\begin{array}{l}\text { Average } \\
\text { Min. } \\
\text { Max. }\end{array}$ & $\begin{array}{r}11.6 \\
<\text { LOD } \\
21.7\end{array}$ & $\begin{array}{r}9.5 \\
<\mathrm{LOD} \\
9.5\end{array}$ & $\begin{array}{r}0.3 \\
<\mathrm{LOD} \\
0.5\end{array}$ \\
\hline$p, p^{\prime}-\mathrm{DDE}$ & $\begin{array}{l}\text { Average } \\
\text { Min. } \\
\text { Max. }\end{array}$ & $\begin{array}{r}40.6 \\
3.6 \\
217.3\end{array}$ & $\begin{array}{r}280.9 \\
1.5 \\
621\end{array}$ & $\begin{array}{r}4.7 \\
0.4 \\
20.2\end{array}$ \\
\hline$p, p^{\prime}-\mathrm{DDD}$ & $\begin{array}{l}\text { Average } \\
\text { Min. } \\
\text { Max. }\end{array}$ & $\begin{array}{r}16.9 \\
<\text { LOD } \\
61.2\end{array}$ & $\begin{array}{r}26.2 \\
<\text { LOD } \\
39.6\end{array}$ & $\begin{array}{r}0.9 \\
<\text { LOD } \\
1.6\end{array}$ \\
\hline РCB 118 & $\begin{array}{l}\text { Average } \\
\text { Min. } \\
\text { Max. }\end{array}$ & $\begin{array}{r}11.0 \\
1.1 \\
26.5\end{array}$ & $\begin{array}{r}62.4 \\
0.33 \\
150.8\end{array}$ & $\begin{array}{l}0.9 \\
0.2 \\
2.9\end{array}$ \\
\hline PCB 138 & $\begin{array}{l}\text { Average } \\
\text { Min. } \\
\text { Max. }\end{array}$ & $\begin{array}{r}26.7 \\
2.2 \\
92.9\end{array}$ & $\begin{array}{r}115.8 \\
0.6 \\
294.2\end{array}$ & $\begin{array}{l}1.9 \\
0.6 \\
6.4\end{array}$ \\
\hline РCB 153 & $\begin{array}{l}\text { Average } \\
\text { Min. } \\
\text { Max. }\end{array}$ & $\begin{array}{r}24.5 \\
2.5 \\
75.7\end{array}$ & $\begin{array}{r}115.0 \\
0.6 \\
369.2\end{array}$ & $\begin{array}{l}1.8 \\
0.5 \\
6.1\end{array}$ \\
\hline РCB 180 & $\begin{array}{l}\text { Average } \\
\text { Min. } \\
\text { Max. }\end{array}$ & $\begin{array}{r}25.4 \\
<\text { LOD } \\
86.1\end{array}$ & $\begin{array}{r}166.4 \\
1.34 \\
657.9\end{array}$ & $\begin{array}{r}1.9 \\
<\text { LOD } \\
4.2\end{array}$ \\
\hline$\Sigma \mathrm{PCBs}$ & $\begin{array}{l}\text { Average } \\
\text { Min. } \\
\text { Max. }\end{array}$ & $\begin{array}{r}83 \\
7.6 \\
247.3\end{array}$ & $\begin{array}{r}459.7 \\
2.9 \\
1472.1\end{array}$ & $\begin{array}{r}5.8 \\
1.5 \\
19.5\end{array}$ \\
\hline
\end{tabular}

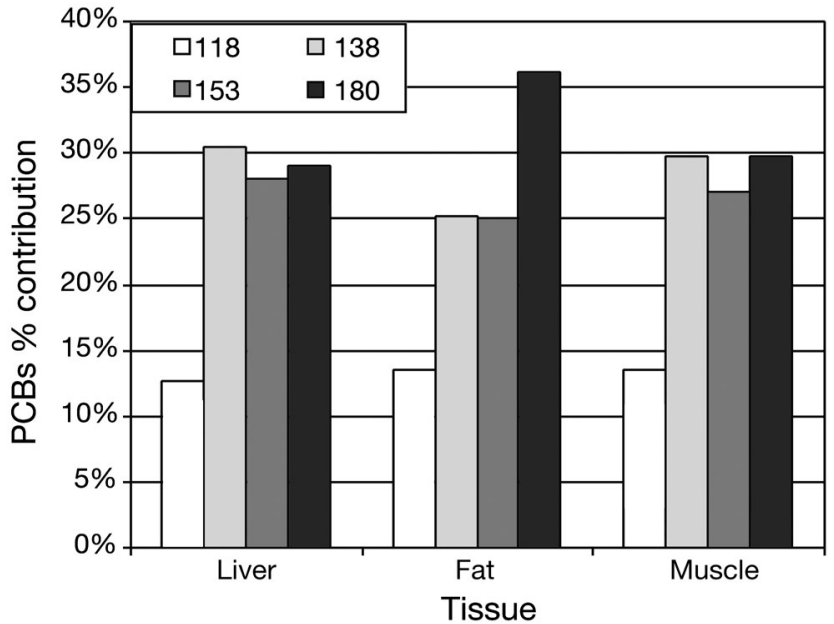

Fig. 3. Caretta caretta. Distribution pattern of PCB congeners (percent contribution to totals) of loggerhead liver, fat, and muscle tissues

the other hand, to their wide presence in the marine environment (Kyu Kim et al. 2002). In fact, as loggerheads are located at the top of the marine food chain and show a slow metabolic degradation rate (Dunson 1984), the PCB levels detected should represent the final result of the biomagnification process.

The average of total PCB concentrations, expressed in nanograms per gram wet weight, was $459.6 \mathrm{ng} \mathrm{g}^{-1}$ in fat, $82.9 \mathrm{ng} \mathrm{g}^{-1}$ in liver, and $5.8 \mathrm{ng} \mathrm{g}^{-1}$ in muscle (Table 3) and $1600 \mathrm{ng} \mathrm{g}^{-1}$ lipid in fat, $1296.3 \mathrm{ng} \mathrm{g}^{-1}$ lipid in liver, and $1248.6 \mathrm{ng} \mathrm{g}^{-1}$ lipid in muscle. Significant differences among tissues were found only for the concentrations calculated on fresh weight, and this difference in contamination levels should be dependent on the quantity of lipids present and typical of each turtle $(p<0.05)$. The average values reported in this study were very similar to those detected in turtles from the central Adriatic Sea by Corsolini et al. (2000). Specimens analyzed by Corsolini had average concentrations, on a wet weight basis, of $234 \mathrm{ng} \mathrm{g}^{-1}$ in fat, $69.7 \mathrm{ng}$ $\mathrm{g}^{-1}$ in liver, and $7.8 \mathrm{ng} \mathrm{g}^{-1}$ in muscle, for the sum of PCBs 118, 138, 153, and 180. In contrast, higher concentrations were detected in loggerhead turtles from the Atlantic Ocean (Rybitski et al. 1995), but lower concentrations were found in loggerhead turtles from the eastern Pacific Ocean (Gardner et al. 2003). These differences could probably be attributed to either the geographical origin of specimens, exposure and local pollution, or typical features of samples, such as age, lipid content, sex, and specific metabolism. Certainly, the PCB pattern found in our turtles, hexachlorobiphenyls > heptachlorobiphenyl > pentachlorobiphenyl, similar in fat, liver, and muscle tissues, is also the typical pattern found in other marine organisms living in the Adriatic Sea, as reported in previous stud- 
ies (Corsolini et al. 1995, Pastor et al. 1996, Perugini et al. 2004).

PCB concentrations in liver, fat, and muscle, were not correlated to the carapace length of single subjects $\left(\mathrm{r}^{2}=0.005\right.$ for liver, $\mathrm{r}^{2}=0.0264$ for fat, and $\mathrm{r}^{2}=0.132$ for muscle) and were not correlated to concentrations of OCs either $\left(r^{2}=0.013\right.$ for liver, $r^{2}=0.227$ for fat, and $r^{2}$ $=0.051$ for muscle), confirming the presence of different sources of pollution in the marine ecosystem.

\section{CONCLUSIONS}

Pollutant concentrations recorded in tissues of loggerhead turtles reveal evidence of a ubiquitous chemical contamination in the Adriatic Sea. Among the PCBs we detected, the presence of penta-, hexa-, and heptachlorinated congeners was notable, and, among organochlorine pesticides, the presence of DDTs. This reflects the pattern shown by other studies of the same organisms. Our contamination levels were lower than those detected in specimens coming from industrialized and polluted areas such as the Baltic Sea or the Atlantic Ocean. The significant spatial difference found for DDT compounds, as well as that not found for PCB compounds, also confirms the wide distribution of PCBs in the marine environment. We cannot ascribe the death of turtles to the amount of pesticides detected in them, because, on the one hand, if OCs and PCBs are considered to have the potential for endocrine disruption, their effects on marine turtles remain undocumented and, on the other hand, the cause of death was known (incidental fisheries) for some samples. It seems that adult turtles may be particularly resistant to toxic effects. As compounds are removed to adipose tissues, they do not show the toxicological effects of pollutants, at least in healthy animals and during periods of food abundance (Lassiter \& Hallam 1990). Hopefully, the results reported here will provide a baseline for future analysis of loggerhead turtle tissues. They should, however, also be combined with DNA analysis, above all, to supply a molecular marker that would allow the identification of feeding and nesting sites of turtle populations, in order to monitor the pressure exerted on all marine turtle populations from developing countries on the Mediterranean.

Acknowledgements. We thank our collaborators at the Centro Studi Cetacei for providing the loggerhead turtles during this project and future projects. This is a contribution to Centro Studi Cetacei ONLUS work No. 105.

\section{LITERATURE CITED}

Basso R (1992) Osservazioni e ricerche sulle tartarughe marine presenti nei mari italiani. Ed del Grifo, Lecce, p 72
Bentivegna F, Hochscheid S, Minucci C (2002) Seasonal variability in voluntary dive duration of the Mediterranean loggerhead turtle Caretta caretta. Sci Mar 67(3):371-375

Bjorndal KA, Bolten AB, Martins HR (2000) Somatic growth model of juvenile loggerhead sea turtles Caretta caretta: duration of the pelagic stage. Mar Ecol Prog Ser 202: 265-272

Casale P, Laurent L, De Metrio G (2003) Incidental capture of marine turtles in the northern Adriatic Sea by Italian trawlers. In: Margaritoulis D, Demetropoulos A (eds) Barcelona Convention-Bern Convention-Bonn Convention (CMS). Nicosia Proceedings of the 1st Mediterranean conference on marine turtles, p 15

Corsi I, Aurigi S, Focardi S (2001) Toxicological evaluation of organochlorine levels: specimens from the Adriatic Sea. In: Faranda FM, Guglielmo L, Spezie G (eds) Mediterranean ecosystems: structures and processes, Vol 9. Springer-Verlag, Heidelberg, p 72-76

Corsolini S, Focardi S, Kannan K, Tanabe S, Borrell A, Tatsukawa R (1995) Congener profile and toxicity assessment of polychlorinated biphenyls in dolphins, sharks and tuna fish from Italian coastal waters. Mar Environ Res 40(1): $33-53$

Corsolini S, Aurigi S, Focardi S (2000) Presence of polychlorobiphenyls (PCBs) and coplanar congeners in the tissues of the Mediterranean loggerhead turtle Caretta caretta. Mar Pollut Bull 40:952-960

D.M. (Decreto Ministeriale) (1989) Disciplina della cattura dei cetacei, delle testuggini e degli storioni. Gazzetta Ufficiale n. 113 of 17/05/1989 Istituto poligrafico della Stato, Roma

Dunson WA (1984) The contrasting roles of the salt glands, the integument and behaviour in osmoregulation of marine and estuarine reptiles. In: Pequeux A (ed) Osmoregulation in estuarine and marine animals. Springer-Verlag, New York, p 107-129

Fernandez MA, Gomara B, Bordajandi LR, Herrero L, Abad E, Abalos M, Rivera J, Gonzàlez MJ (2004) Dietary intakes of polychlorinated dibenzo-p-dioxins, dibenzofurans and dioxin-like polychlorinated biphenyls. Food Addit Contam 21(10):983-991

Focardi S, Ademollo N, Guerranti C, Fossi S and 5 others (2001) Polychlorinated-biphenyls, -dibenzo-p-dioxins and -dibenzofurans in commercial seafood species in Italy. XI Congresso S.It.E, Sabaudia, p 108

Fox GA (2001) Wildlife as sentinels of human health effects in the Great Lakes-St. Lawrence Basin. Environ Health Perspect 109(1.6):853-861

Gardner SC, Pier MD, Wesselman R, Juarez JA (2003) Organochlorine contaminants in sea turtles from the eastern Pacific. Mar Pollut Bull 46:1082-1089

Huwe JK (2002) Comparison of soxhlet and accelerated solvent extractions. In: The analysis of dioxins and furans from liver samples. Organohalogen Compounds 58:229-232

Keller JM, Kucklick JR, Harms CA, McClellan-Green PD (2004) Organochlorine contaminants in sea turtles: correlations between whole blood and fat. Environ Toxicol Chem 23(3):726-738

Kyu Kim S, Soo Lee D, Ryong Oh J (2002) Characteristics of trophic transfer of polychlorinated biphenyls in marine organisms in Incheon north harbor, Korea. Environ Toxicol Chem 21(4):834-841

Lassiter RR, Hallam TG (1990) Survival of the fattest: implication for acute effects of lipophilic chemicals on aquatic populations. Environ Toxicol Chem 9:585-595

Laurent L, Nouira S, Jeudy de Grissac A, Bradai MN (1990) Les tourtues marines de Tunisie: premières données. Bull Soc Herpetol Fr 53:1-7 
Laurent L, Abd El-Mawla EM, Bradai MN, Demirayak F, Oruç A (1996) Reducing sea turtle mortality induced by Mediterranean fisheries: trawling activity in Egypt, Tunisia and Turkey. WWF Project 9EO103, World Wildlife Fund

Laurent L, Casale P, Bradai MN, Godley BJ and 14 others (1998) Molecular resolution of marine turtle stock composition in fishery bycatch: a case study in the Mediterranean. Mol Ecol 7:1529-1542

Limpus CJ (1990) Puberty and first breeding in Caretta caretta. In: Proceedings of the 10th annual workshop on sea turtle biology and conservation. NOAA Tech Memo NMFS 278:81

Livingstone DR, Chipman JK, Lowe DM, Minier C, Mitchelmore CL, Moore MN, Peters LD, Pipe RK (2000) Development of biomarkers to detect the effects of organic pollution on aquatic invertebrates: recent molecular, genotoxic, cellular and immunological studies on the common mussel (Mytilus edulis L.) and other mytilidis. Int J Environ Pollut 13(1-6):56-91

McKenzie C, Godley BJ, Furness RW, Well DE (1999) Concentrations and patterns of organochlorine contaminants in marine turtles from Mediterranean and Atlantic waters. Mar Environ Res 47:117-135

Editorial responsibility: Otto Kinne, Oldendorf/Luhe, Germany
Pastor MD, Sanchez J, Barcelo D, Albaiges J (1993) Determination of coplanar polychlorobiphenyl congeners in biota samples. J Chromatogr 629:329-337

Pastor D, Boix J, Fernandez V, Albaiges J (1996) Bioaccumulation of organochlorinated contaminants in three estuarine fish species (Mullus barbatus, Mugil cephalus and Dicentrarcus labrax). Mar Pollut Bull 32 (3):257-262

Perugini M, Cavaliere M, Giammarino A, Mazzone P, Olivieri V, Amorena M (2004) Levels of polychlorinated biphenyls and organochlorine pesticides in some edible marine organisms from the central Adriatic Sea. Chemosphere 57: 391-400

Rybitski MJ, Hale RC, Musick JA (1995) Distribution of organochlorine pollutants in Atlantic sea turtles. Copeia 2: 379-390

Snover ML (2002) Growth and ontogeny of sea turtles using skeletochronology: methods, validation and application to conservation. PhD thesis, Duke University, Durham

Storelli MM, Marcotrigiano GO (2000) Chlorobiphenyls, $\mathrm{HCB}$, and organochlorine pesticides in some tissues of Caretta caretta (Linnaeus) specimens beached along the Adriatic Sea, Italy. Bull Environ Contam Toxicol 64: $481-488$

Submitted: August 19, 2005; Accepted: March 30, 2006

Proofs received from author(s): July 10, 2006 